\title{
Noel Buxton: The 'Trouble-Maker' and His Papers
}

\section{by Robert Vogel}

The papers of Lord Noel-Buxton represent an essential tool for anyone interested in the formulation of British Foreign Policy from "Agadir to Yalta." Buxton was a member of a distinguished old British family which had been deeply involved in Christian canses from the abolition of slavery to the peace movements in the 20th Century. Noel Buxton uas a vigorous advocate of many important causes and bis papers reflect activities ubich brought bim into contact and correspondence with a vast range of interesting people from Turkish terrorists (ubo tried to assassinate bim), to Adolf Hitler. Haile Salassie, Neville Chamberlain and Winston Churbill. This is one of the true treasures of the McGill manuscript collections.

Le fonds de Lord Noel-Buxton sont un ontil précieux ponn quiconque s"intévesse à la formulation de la politique étrangère britannique "d'Agadir a Yalta". Buxton appatenait à une vieille famille britannique de la baute société, qui a défendu les canses chrétiennes depmis l'abolition de l'esclavage jusqu'aux mouvements pacifistes du $20^{\circ}$ siècle. Noel Buxton a été l'ardent défenseur de grandes causes. Ses documents refletent les activités qui l'ont amené à fiéquenter une brochette très lariée de personnalités intéressantes avec lesquelles il a échangé mue comrespondance. comme les terroristes turcs (cenx-là même qui ont tenté de l'assassiner), et d'antres personnages commure Adolf Hitler, Haile Salassie, Neville Chamberlain et Winston Churchill. C'est l'un des plus authentiques trésors des collections manuscrites de l'Université McGill.

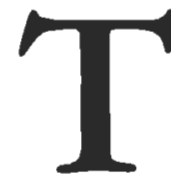

here is a legend which circulates among some of the older graduate students of the History Department that McGill acquired the great collection of Lord Noel-Buxton's papers in the following manner. One fine summer's day, Prof. H. N. Fieldhouse' of the History Department wandered into Fernhill, the country residence of the then Lord NoelBuxton and charmed the son of the first Lord into giving all of his father's papers to McGill University. As so often with good legends there is some truth to this story. Prof. Fieldhouse did go to Fernhill in the summer of 1968 and he did indeed come away from there with some documents which have now been added to the Buxton collection, but the main bulk of that collection was acquired by the University in 1961.

However there does remain an essential truth to the legend, because it was the enthu- siasm and the academic interests of Prof. Fieldhouse which led to the original acquisition, at a time when he was Dean of McGill College and when Deans still had academic interests. But as befits a good legend, there is also an element of mystery about the papers themselves. When Mosa Anderson wrote her biography of Noel Buxton, ' which was published in 1952, his papers were clearly still in one place and made available through the good offices of Lady Noel-Buxton. What happened to the collection of papers after that is unclear. The 1974 Guide to the Papers of British Cabinet Ministers says that "..Lord Noel-Buxton tells us that he does not know how the papers came to leave his family's possession." Certainly a number were bought by Professor William Hamilton for the William R. Perkins Library of Duke University. Both McGill's and Duke's collections were bought from dealers in England who had apparently obtained them from agents who found them 
'at house sales' or 'in old desks'. As recently as 1985 Sotheby's auctioned a series of letters under the heading of 'Papers of Lord NoelBuxton' which contained items which were quoted in full in the Anderson biography. For instance the letter from Neville Chamberlain dated October 14th 1938 is quoted in the biography on p. 141 and was item 438 of the Sotheby's catalogue.' So some mystery remains. What is not a mystery is that in 1968 Lord Noel-Buxton was pleased to give to Fieldhouse some documents which augmented the McGill collection, facilitating the continuing work on his father's carecr. Prof. Fieldhouse was thus responsible for bringing another major collection to McGill, just as he had previously been instrumental in bringing the papers of Henry Hardinge, Viscount Hardinge. These two of the collections which make the McGill library such an important place for certain aspects of modern British History.

The Buxton collection occupied a very special place in Prof. Fieldhouse's academic life. His interest in British foreign policy was a lifelong one; he had made his reputation in the 1930's with a series of articles on Bolingbroke which combined the exploitation of hitherto untapped manuscript sources in relation to Bolingbroke's peace negotiations with France, with an analysis of his political ideas and the major domestic questions in the first half of the eighteenth century. The influence of Lord Noel-Buxton on British foreign policy, 'which spanned over the whole first half of twentieth century, would fully engage the last part of Prof. Fieldhouse's academic career.

\section{THE BUXTON FAMILY}

Lord Noel-Buxton (Figure 1) was a man of considerable importance and influence. He came from a family which is a genealogist's dream"; the Noels had come over with the Conqueror and the Buxtons were well established by Elizabeth's reign in Coggeshall, Essex, one of the chief centers of the clothmaking industry in the 15 th and 16 th century. "There was considerable wealth in the family which came largely from a brewery in Spitalsfields, but fame came from a variety of other accomplishments. Almost every gener- ation in the British past is likely to turn up a number of prominent persons who were closely related to the Buxton family. At the beginning of the nineteenth century, for instance, there was Lord Barham, the First Lord of the Admiralty, who ordered the disposition of the Royal Navy at the time of Trafalgar, Elizabeth Fry, who can need no introduction as the most influential prison reformer of the century and Sir Thomas Fowell Buxton, Elizabeth Fry's brother-inlaw, who inherited Wilberforce's" leadership of the abolition movement in the British Empire and who was known as the the Liberator'. It was his persistent advocacy in the House of Commons that brought about the 1833 Act to abolish slavery in the British Empire. Noel Buxton was extremely proud of his great-grandfather and commissioned a biography of him." These were only the most outstanding of a long line of very influential members of the family. They also exemplify the kinds of concerns which occupied the family throughout the nineteenth and twentieth centuries.

Although the Buxtons had been Independents of the kind that had followed Cromwell in the seventeenth century, they had converted to the Anglican Church in the eighteenth and were thus able to sit in the House of Commons. "' Their religious inspiration now came from their frequent marriages into prominent Quaker families, whose social conscience seemed to provide the motivation for many of the actions of the Buxtons. In the nineteenth century this religious inspiration was deepened by the evangelical movement in the Anglican Church, which profoundly influenced the members of the Buxton family and certainly Noel Edward Buxton (1869-1948).

There can be no doubt that the motivation for Buxton's actions came from the a deeply felt and clearly articulated Christianity. There was an almost awesome quality in the consistency with which Buxton saw the world and in the way in which he proposed to alleviate its sufferings. It was always done with the same determination and with the same gentle humility which was so terribly disarming to his opponents. Above all whatever cause Buxton took up, he appeared to bear no mal- 
Noel Buxton: The 'Trouble-Maker' and His Papers

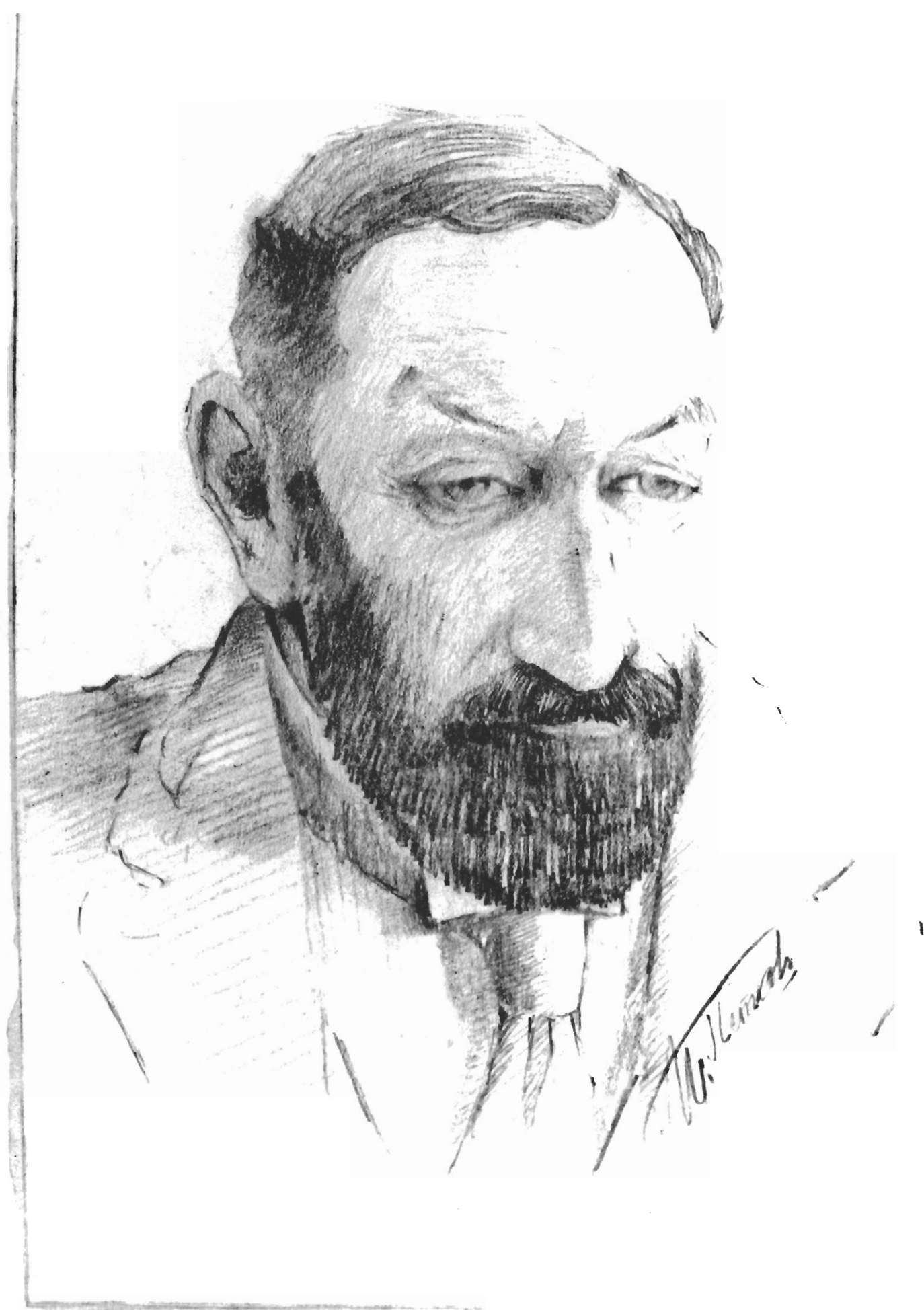

Figure 1. A portrait, in pencil, of Noel Buxton after he grew his beard to hide the scar from the assassination attempt. (Noel Buxton Papers.) 
ice even against those who might legitimately be held responsible for the suffering. The world was indeed as God made it but I.Ie had, at the same time, made it virtually mandatory for true Christians, who were more fortunate than other people, to provide charity, but only in the true meaning of that word, that is expressing love for one's fellow human beings by helping them to overcome their difficulties. Many of the causes which he took up were ones which were almost traditional in the family but they were no less important or less worthy for that reason. Some, like the Balkan question, he made uniquely his own and some, as in the case of Great Britain's relations with Germany, were simply part of the reality of the twentieth century. But of course, what was extraordinary was the number of such causes which engaged Buxton's attention and which benefited enormously from that attention.

\section{BUXTON'S CAREER}

One can perhaps usefully divide his "causes" into three kinds. Those which were essentially concerned with British domestic problems, those which dealt with issues which could be related to British foreign policy and those which were essentially attempts simply to alleviate human suffering everywhere, particularly that of children. Buxton's participation in these 'causes' was always active in two senses, one was that each entailed correspondence with an enormous number of people and the other was that Buxton was a person who wanted to see for himself, a necessity which entailed an almost unbelievable amount of travel. A simple list of Buxton's journeys from 1890 to 1939 alone provide a startling reminder of the enormous energy of the man. He only rarely travelled for pleasure, but there was no part of the world where he did not recognize beauty and poetry as well as human suffering. In 1892 he and a friend sailed around the world and there are, in the papers at McGill, the letters which he wrote virtually every day to either his father or his mother with a full description of what he saw and did. The letters reveal much about Buxton, his interest in people, his abhorrence of injustice, his knowledge of agriculture and his admiration for the new kind of social equality which he thought existed in Australia and New Zealand."

But many of Buxton's journeys were to much wilder and more dangerous places than Australia and New Zealand. He describes some of these in his book on Travels and Reflections which he published in 1929;': he had confronted bands of marauders several times in very wild parts of the world and there was a serious attempt to assassinate him and his brother in 1914, nevertheless he was indefatigable. In 1932, in his sixty-fourth year, he was off in Abyssiania, lecturing and cajoling the Emperor, Haile Selassie, to abolish slavery; in 1938, at seventy, he was in Germany lecturing National Socialists on the virtues of Christianity. Almost every journey involved some issue that he wanted to report on or speak to and therefore entailed much writing in the form of reports, letters and lecture preparation, particularly when they were issues which he felt demanded a change in the current British policy.

The papers at McGill contain several drafts of an autobiography ${ }^{13}$ which list some of the domestic causes which engaged Buxton's attention especially in his earlier years. Unfortunately there are not very many other papers relating to these activities. Nevertheless all of the characteristics of the 'activist' in causes taken up later were already present. Beginning with the self-examination. "Was it right for a Christian to be a brewer at all?' and moving to action in terms of an ambitious scheme of management for public houses in which managers would have no monetary interests in the selling of alcohol. This scheme was known at the time as the Gothenburg system and had been tried in parts of Germany and Scandinavia. Buxton visited Stockholm and Gothenburg, persuaded the famous (harles Booth to write a preface to an anonymous article on the subject, naturally written by Buxton.

Two large scale experiments were attempted later: the People's Refreshment House Association and the Public House Trust Association. His other domestic causes included Poor Law Reform, Town Gardening, a movement in which his wife was also 


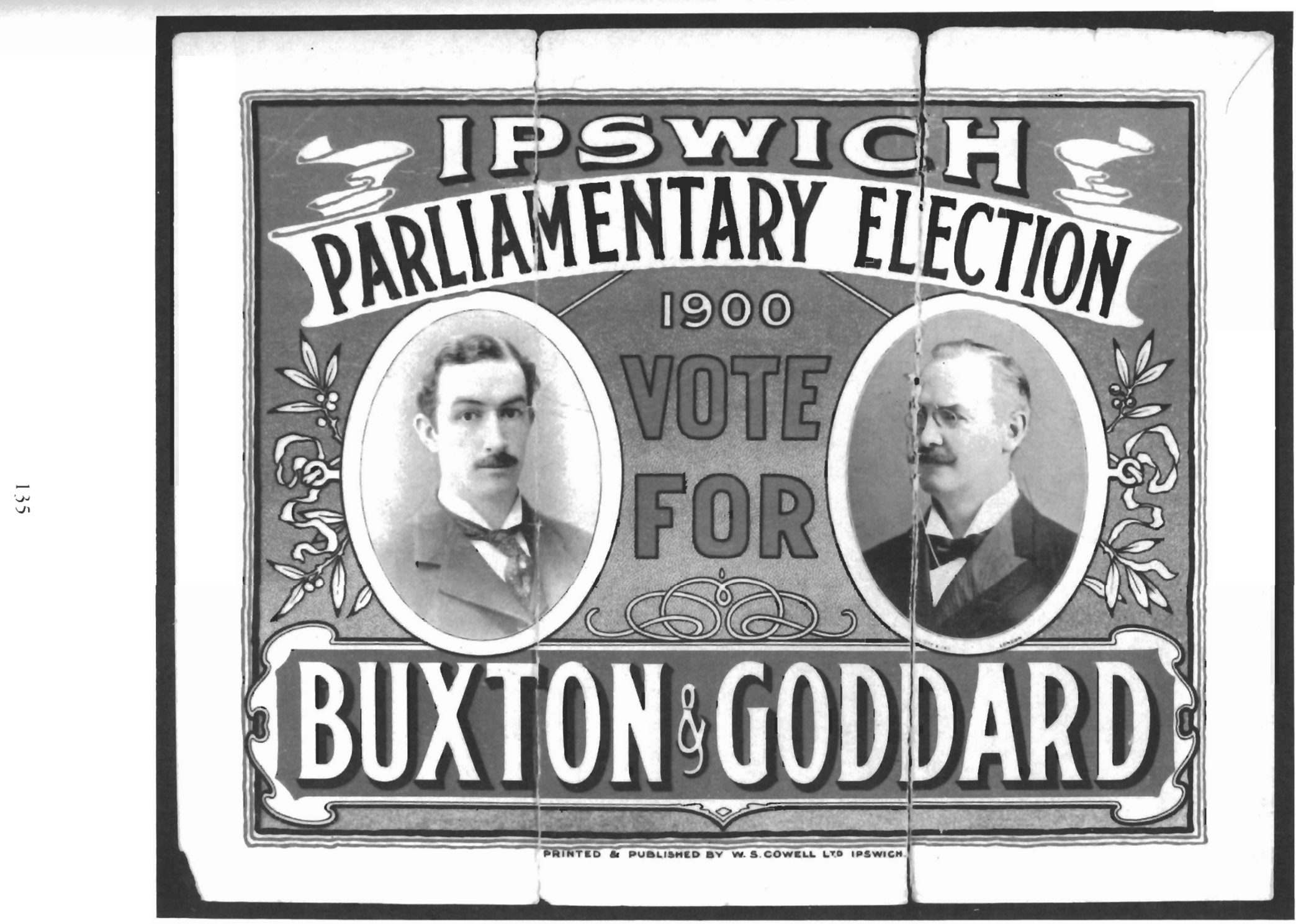

Figure 2. Buxton was defeated at his first attempt to enter Parliament for Ipswich in 1900 and in his second attempt for Whitby in 1906. (Noel Buxton Papers.) 
involved, agricultural co-operation, housing and the humane slaughter of animals. These areas of activity all fitted into the general reforming temper of those who saw themselves and the Liberal Party as the heirs of Gladstone. They also led almost irresistibly to a need for a seat in the House of Commons (Figure 2).

Buxton won a seat as a Liberal in a by-election in Whitby in 1905 but lost it in the general election of 1906. In 1910 he was elected for North Norfolk, a seat which he held until 1918. His differences with the Lloyd George wing of the Liberal Party over the question of the German peace, led him to join the Labour Party and he won back the North Norfolk seat as a Labour candidate in 1922. He became Minister of Agriculture in the first and again in the second Labour Government (Figure 3) and was able to implement some of his ideas, particularly with regard to humane slaughter and agricultural labour. He resigned on the grounds of ill-health in 1930 and was persuaded to take a seat in the House of Lords as one of the few Labour Peers. He had serious doubts about accepting a peerage ${ }^{1+}$ and took the title of Noel-Buxton rather than a more usual title with a place name. ${ }^{15}$ His wife stood for and won the House of Commons seat vacated by him. ${ }^{16}$ These domestic activities of Buxton, however, are not as well represented in the McGill collection as are his interests in foreign policy. ${ }^{1 ?}$

These interests can readily be divided into a number of special areas: the Turkish Empire generally but more specifically the problems of Turkish rule in the Balkans and Armenia; the Anti-Slavery Society and in particular the question of the continued existence of slavery in Abyssiania; the whole problem of Britain's relationship with Germany before the Great War, the attempts to find a negotiated peace during the War, particularly in 1916 and 1917 , the fierce debate over the Versailles settlement, the crisis of the 1930 s and then again the attempt to find a negotiated peace between 1939 and 1942. A common thread binds all of Buxton initiatives in British foreign policy, which places him squarely in the 'radical tradition's. Buxton wanted to bring to the foreign policy of his country the kind of concern for human freedom which informed his general view of life. This attitude usually led him into opposition with the policy makers, whose concerns naturally were more at home in the world of power politics.

\section{THE BALKAN QUESTION}

The 'Balkan Committee' was typical of Buxton's approach. He was convinced that Great Britain had a special responsibility with regard to Macedonia. Under the provisions of the Treaty of San Stefano (1878) large sections of Macedonia had been assigned to Bulgaria, but Disraeli's policy had forced Russia to agree to the Congress of Berlin (1878) and to the restoration of considerable parts of Macedonia to Turkish rule. Buxton felt that therefore Britain had a special obligation to see that this restored province was properly governed. He visited the Balkans for the first time in 1899 and was appalled by conditions there. In 1902 he founded the Balkan Committee, induced Lord Bryce to become its President, and set about trying to persuade the Foreign Office to take some responsibility for the situation there. The founding of the Committee barely preceded the next major uprising in 1903; an uprising which was clearly the result of continuous Turkish misgovernment and the rise of various nationalist terrorist organizations ${ }^{19}$ supported by Greek, Serbian or Bulgarian Governments.

The work of the Balkan Committee takes up much space in the McGill collection. There are twelve boxes and another substantial group of unnumbered files ${ }^{20}$ full of speeches and correspondence; documents which reflect both the strengths and weaknesses of Buxton's initiatives and both the limitations and the strength of the commitment which Buxton's character brought to his endeavours. While the main focus in the early years was on the problems of Macedonia, concern over the mistreatment of the Armenian population was also very much in the minds of Committee members. One of the great difficulties of dealing with that question, however, was that Armenia was even more inaccessible than the mountains of Macedonia.

The strength of the Balkan Committee lay from the beginning in the fact that its men- 


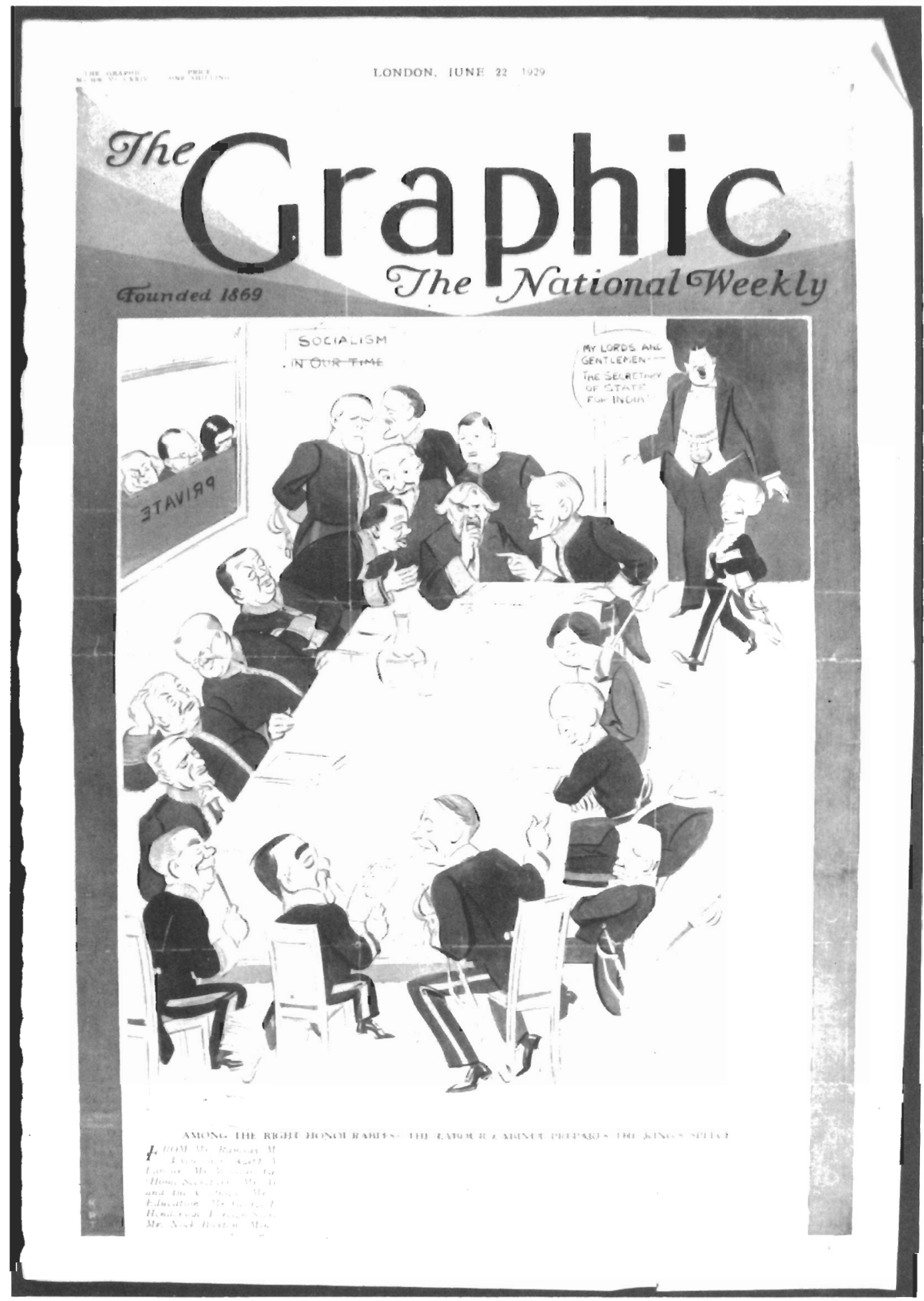

Figure 3. Buxton is the bearded figure standing in the middle of the group of three at the rear (arrow). (Noel Buxton Papers.) 


\section{Noel Buxton: The 'Trouble-Maker' and His Papers}

bers were very well connected in British political life. The letter-head always contained a judicious mixture of Bishops, politicians, journalists, professors as well as wealthy businessmen. The absolute respectability of the Committee, (as was only proper for any heir to Gladstone's policy) always gave the Chairman ready access to the leaders of the British Government. When members of the Committee travelled on the Continent they were received everywhere first by British Ambassadors, then by Foreign Ministers and, in the Balkan states themselves, by the heads of governments from the Sultan on. Since they were free from any commitments to anyone or any state, they could advocate policies which were untainted by any smell of self-interest. They advocated such policies with righteous indignation about the inactivity of others which naturally made them a source of enormous irritation to foreign ministers generally, ${ }^{21}$ including, on occasion, the British one. On the other hand they did advocate generally sensible and moderate policies, rare advice in the Balkan tangle. With a sympathetic British Foreign Secretary, like Lord Lansdowne, they had some successes. After the Macedonian uprising and the horrendous methods employed by the Turkish Government in its suppression, Lansdowne was sympathetic enough to order a 'Naval demonstration', which persuaded the Turk ish Government to agree to the demands of the Powers to install an international gendarmery in Macedonia and to make a variety of other concessions. Unfortunately Lansdowne's successor, Sir Edward Grey was not nearly as easily convinced of the correctness of the course advocated by the Balkan Committee.

A particular strength of the Committee was that it could change its mind about its policies without any reference to anyone. For instance Buxton became convinced after 1908 that the Turkish Revolutionary Movement, the Young Turks, could effect reforms and so the Committee, for a short while, supported the Turkish Empire, just at the moment when the British rapprochement with Russia was moving British policy in the opposite direction. When the Young Turks proved as difficult as the old ones, particularly with respect to the Armenians, the Committee once again moved against continued Turkish rule, but before any new policy could be advocated, the Balkan wars had changed everything again.

The weaknesses of the Committee were in some respects obvious. No one on the Committee wanted to overthrow the Liberal Government which had been elected in 1905 and which after all represented the Party to which Buxton and many members of the Committee belonged. They did of course object to the whole 'imperialist' wing of the Party which was that of Sir Edward Grey and Mr. Asquith, but their main aim was to persuade Grey of the rightness of their policy and they did this without accusing him of wickedness. They were, therefore, entirely dependent on persuading the Foreign Office and ultimately the British Cabinet to act on their behalf. As such actions would have necessitated a major shift in British policy towards the other Powers, most British Foreign Ministers, even when they were Labour Foreign Ministers, were reluctant to undertake them.

Another clear weakness was that the very single-mindedness of the Committee made it difficult for its members to appreciate the enormous complications of the problems faced by the Powers in the Balkans, as well as everywhere else. The very idea that there was a connection between, for example, British policy towards Germany and British policy towards Turkey seemed to men like Buxton inherently wicked. However that made them incapable of fathoming many of the intricacies of foreign policy, even within the relatively narrow boundaries of the Balkan Peninsula. Certainly there was a good deal of unwarranted optimism in the Committee's view of what was likely to happen in the Balkans, ${ }^{22}$ and little understanding of the broader issues involved.

Such shortcomings were in many ways inherent in all movements which advocated particular changes in British policy. Nevertheless protest movements which concentrated on a single issue which could be clearly defined had often been successful during the last century in Britain. From the movement to abolish the slave trade to the Congo Reform Association, success had depended on 
the clarity with which the cause could be defined and the single-mindedness of the leadership. Buxton, however, was too good a Christian to impose his views unreservedly on others. He rarely followed a single cause to the exclusion of all the others and his views were seldom utopian, never intolerant. That together with his tendency to carry his message by reasoned memoranda rather than at mass meetings made him less of a public figure', less of a threat to governments. He did appear on public platforms occasionally but he preferred to work by persuading ministers of the inherent rightness of his policy. Such methods took much time and often by the time the right people had been convinced, the policy needed to be changed. ${ }^{23}$ Also it was surely true that while reason and Christianity might persuade a few British statesmen, that particular combination was not likely to influence many of the other leaders of the first part of this century.

On the other hand his personal commitment to the basic humanitarian cause was total. He wanted to see for himself and so he travelled to the Balkans virtually every year in the first ten years of the Committee's existence. These were not always comfortable or pleasant journeys. During the Balkan wars he and his brother found themselves in a Bulgarian hospital in Kirk Kilise where wounded were pouring in and where there was a general shortage of personnel. They began work there, dressing the wounds and preparing the wounded for the operating room. All of this is described very graphically by Buxton in an article which he wrote in the Contemporary Review February 1913'' because he felt that it was vital for people to realize the true facts of the horrors of war and the wounded if they were ever going to be able to diminish suffering and war.

The Christian foundation of his character was even more in evidence in 1914. After the outbreak of war with Germany, there was of course still the question of which side Turkey and Bulgaria would take. Buxton felt that he could persuade the Bulgars not to join the Central Powers, perhaps even to come in on the Allied side. Lloyd-Geoge and Churchill encouraged him in this endeavour but Grey was somewhat more hesitant. In any case Buxton and his brother Charles rushed off by train to Brindisi, then via British warship to Salonika and from there to Sofia. The diplomacy of the mission and the reasons for Grey's hesitant stance are quite outside the scope of this essay but it is important to realize that the Buxtons arrival in Sofia was a major event and, although the pro-Austrian Government had had little to do with pro-Entente diplomats for some time, they were warmly received by King Ferdinand. Nevertheless they departed empty handed. They went on to Bucharest where a somewhat similar situation had arisen. Here again they were received by the King and Queen who were pleasant enough but not willing to change their ideas. In the early hours of the morning after the Buxtons' visit to the palace King Carol died suddenly which naturally allowed some to whisper that Buxton had poisoned him.

On the day of the King's funeral, a Turk, who had been following them since Sofia, took advantage of the crowded square in front of their Hotel and emptied his revolver at them at close range. Both brothers were wounded, Charles was shot through the lungs and Noel had a bullet in his jaw. They were carried back into the hotel and even before proper medical help arrived the police brought the man who had been captured into their room for identification. They were finally taken to hospital where they spent about a month. Both men recovered well, although Noel would grow a beard to hide the scar which stayed with him for the rest of his life. The brothers visited their would be assassin, whose name was Hassan Taxim, a number of times in the Rumanian prison and discussed his motivation. Hassim was a student who had read philosophy at the Sorbonne and they communicated easily in French. Buxton believed that he established some kind of understanding with his would-be assassin and sent him books and a rug. He also carefully preserved the defense lawyer's summing up. Nevertheless Hassan was convicted by the Rumanian court to five years hard labour in the salt mines, the equivalent of a Rumanian death sentence. However a year later the Germans took Bucharest and Hassan was 
freed. Buxton learned, at the end of the war, through a naval officer who had obviously heard of the Bucharest incident that Hassan was killed when the Greeks took Smyrna. The officer had inquired why certain Turks had been executed and was told that one of them was a hero in the Turkish quarter because he once tried to assassinate two Englishmen. Photographs of the bodies, which were laid out on the quay, were sent to Buxton who readily recognized Hassan amongst them.

The documents at McGill readily substantiate this version of the story of the assassination attempt. They also contain some very touching letters of Buxton to his new wife written from the hospital in Bucharest, letters which lay out Buxton's philosophy of life and his reasons for working in the Balkans. But his Christianity and his general forgiving nature could hardly be better illustrated than in the concern for his would-be assassin, the attempts to mitigate his sentence and to make his life in prison more bearable.

Having recovered from their wounds, the Buxtons went back to Sofia and from there to Nish, where the Serbian government had fled after the fall of Belgrade. They were still pursuing the idea of the possible neutrality of Bulgaria and needed some assurances from Serbia about its ambitions in Macedonia. Both in Serbia and in Greece, where they went next, they saw and negotiated with the PrineMinisters and Kings. The complications of the negotiations belong of course to the history of the Balkans and by and large the mission was not really a success. When they returned to Paris they continued their efforts with long discussions with Deleasse, the French Foreign Minister, Clemenceau and Isvolski, the Russian Ambassador to France. The proposals to satisfy many of the Bulgarian claims to Macedonia, which of course needed the assurances of all the peripheral states and the great Allied Powers seemed to have been obtained but in the end nothing changed Bulgaria's decision to join the Central Powers. The whole expedition does, however, represent the closest that these particular troublemakers' would ever come to conducting their own foreign policy.
Although Buxton continued to pay close attention to events in the Balkans he would never again play such a vital role in the diplomacy of the region. It did not occur to him that he had started his Balkan Committee in an attempt to prevent the continuous violence in the region but that by 1914 he was haggling over bits of territory in a fashion similar to the governments he so readily criticized. And the violence seemed to continue in the 'Christian' states ${ }^{26}$ as in the Turkish state, where A rmenians continued to be killed in substantial numbers. In the final analysis of course the Balkan Committee could find no real solution to Balkan problems. Throughout the period in which Buxton was first its Chairman and then its President, the Committee advocated Balkan unity and national self-determination, clearly both desirable but also obviously incompatible. Of course this terrible contradiction remains one of the basic dilemmas of the twentieth century for which neither the Balkan Committee nor anyone else has yet found a solution.

\section{ANTI-SLAVEIRY AND ABORIGINAL. PROTECTION SOCIETY}

It is entirely fitting that many documents in this collection relate to the question of slavery. Throughout his active political life Buxton was engaged in the work of the Anti-Slavery and Aboriginal Protection Socicty of which for many years he was either President or Co-President. The bulk of the material at McGill relating to this society deals with the question of slavery in Abysinia but there are 3 boxes (26-28) and 19 files concerned with slavery in other areas and the treatment of people generally in various colonies. In 1936 the Society still reckoned that there were more than 5 million people in the world who were slaves. A typical issue of the 'The Anti-Slavery' Reporter and Aborigines Friend' in 1936 contained articles on the following subjects: "The Native Bills in South Africa', which deals with the fact that Native Franchise Bill in the Parliament of the Union of South Africa was disastrous to the representation of native people in that country, two articles about the aborigines of Australia (one being a reply to a previous article by the Commonwealth Prime 
Minister), one article on Mui T'sai in Hong Kong, Land in the Kenya Highlands, Slavery in Abyssinia, the Position of Native Women in Africa and Lynching in the United States.

The work of this Society, like that of the Balkan Committee, showed the strengths and weaknesses of this kind of political action. Although its hope was to effect change in many parts of the world, its influence was really confined to the British Government. Nevertheless this influence was particularly useful at this time because the British Government could and did insist on incorporating some of the ideals of the Anti-Slavery Society into the emerging international structure of the League of Nations. As a result antislavery clauses were incorporated in the Convention of St. Germain-en-Laye of 1919) and an international Slavery Treaty was concluded in 1926, in which the signatories promised to do their best to wipe out slavery and the slave-trade. In this way the Society was successful, but whether the League could ever enforce its own treaties and regulations was another matter and the record of the League was not a good one as the case of Abyssinia clearly illustrated.

The largest number of documents dealing with slavery relate to the question of Abyssinia. ${ }^{2 x}$ In this single issue all the frustrations and the personal commitment of Buxton come together. It is also an issue which Prof. Fieldhouse explored in considerable detail in his work on Buxton, "so that the major outline of the events are well-established. They follow the same pattern, although the dilemma for British policy was even more acute. Abyssinia was a country in which domestic slavery and slave raiding across international boundaries was rife. In the early 1930s there were still large slave markets in Abyssiania, facts that were well known to all of the protagonists in the crisis of 1935-6, although almost invariably ignored in historical accounts of it. The Emperor had made repeated promises to the League to abolish slavery in all its forms. His failure to do so led to the mission of Buxton to Abyssinia in 1932. Despite friendly interviews with the Emperor and a fairly sharp report, nothing very much changed prior to the Italian invasion. That invasion confronted Buxton, and indeed everyone, with the classic dilemma between the modern dictator and traditional society, between foreign conquest and national selfdetermination. "Buxton could not support the flagrant violation of the rights of independent states which the Italian aggression represented. On the other hand the role of innocent victim for Haile Salassie and his government seemed equally repugnant to the President of the Anti-Slavery Society. It was an insoluble problem for Buxton as it was for everyone else concerned with the issue. At least Buxton did not forget what $A$ byssinia represented before the Italian aggression.

When the British Army recaptured Addis Ababa in May 1941, Haile Selassie was so much a martyred victim of fascist aggression that the British Government found it impossible to put pressure on him with regard to the question of slavery. Independence was so precious that one must not besmirch it with advice on such unpleasant subjects as slavery! Buxton's attempts to force the British Government in 1942 and again in 1944 to exert pressure on Haile Salassie met with little success in a Britain which had many other problems. Slavery in Abyssinia was not an issue which moved the British Government during the most critical years of the Second World War. "Ironically if the position of slaves in Ethiopia underwent any amelioration, it would seem to have been due not to the efforts of the reformers but to a by-product of the large spending, by the Italians, on roadbuilding and other construction which, substituting paid (if forced) labour for slavery, did something to fulfil Miss Perham's hope of making the institution 'superfluous'.":

\section{ANGLO-GERMAN RELATIONS}

In some respects Buxton's interventions with regard to the major issue of British foreign policy in the twentieth century, namely the German issue, had equally few positive results (Figure 4). Documents relating to this issue represent a substantial proportion of the documents deposited at McGill. "2 In a sense that is surely natural in that the two powers that stayed in both World Wars from the beginning to the end (although the Second had 
some ragged edges at both ends) were Germany and Great Britain, and the relationship between the two countries also dominated the twenty year peace that separated the two wars. In this situation Noel Buxton and his younger brother, Charles Roden Buxton were 'tireless advocates of Anglo-German reconciliation and friendship'. From the time of the Agadir crisis in 1911, Buxton felt that the Government, wrongly led by Sir Edward Grey, was moving Britain into a confrontation with Germany which was both unnecessary and harmful. The outbreak of war proved to Buxton that he had been right in his fears and he then joined in all the major efforts to bring the war to a negotiated settlement. He felt strongly after the war that there had been many opportunities to end the war on a mutually acceptable basis and that the policy of 'fighting to the finish', for which he blamed Lloyd George, brought with it a Peace Treaty which was a disaster in every respect, moral and diplomatic, one for which Britain would have to pay a very high price.

The feeling of guilt, the belief that Germany had to be appeased, was of course the policy which the Conservative Government adopted in the 1930s but by that time, in Buxton's view, it was already too late and too little. Clearly any serious discussion of this body of opinion, which in fact had a substantial following in Britain would be out of place in this paper dealing with Buxton's papers, but it should be noted that these papers have already been the basis for two works dealing with this aspect of British Foreign policy. The first, published in 1932, is called Foreign Policy from a Back Bench, 1904 - 1918, A study based on the Papers of Lord Noel-Buxton. by T. P. Cornwell-Evans, published in London in 1932. ${ }^{33}$ The author was a close collaborator of Buxton and a great advocate of Anglo-German friendship. The book is a classic statement of the body of opinion which blamed the war on secret diplomacy and the alliance system, which argued that golden opportunities to make a rational peace had been missed during the war, that the conflict illustrated and underlined the futility of war and that the Peace Treaty had been morally wrong and would lead to further conflict. The way to avoid this new conflict was for foreign policy to be controlled by democratic institutions, such as the House of Commons, for the relationship between states to be regulated by 'open treaties, openly arrived at', and, above all, by restoring to Germany a sense of equality, essentially by abrogating the Versailles Treaty and restoring her colonies.

There can be no doubt that all of these sentiments are well represented in the Buxton papers and that indeed Buxton was in the forefront in organizing these opinions both in and out of Parliament. And while his own writings carry a less censorious tone than that of Cornwell-Evans, it is true that Buxton's move to the Labour Party was largely a result of his disapproval of Lloyd-George's actions in Paris and his admiration for Ramsay MacDonald as a man of peace.

Buxton's involvement in peace initiatives during the Second World War is dealt with in Fieldhouse's third major essay based on the Buxton papers. "Ironically the prospective leader who would replace Churchill in order to make peace with Germany was Lloyd George. But Buxton was in the very center of the group searching for a peaceful solution and his ideas and actions were very representative of the whole movement. As Fieldhouse points out, "his wide acquaintance with the 'political nation' opened nearly all doors to him". Here again are the familiar strengths, the enormous correspondence, the endless memoranda and articles, the close collaboration with his brother, Charles, and the many committees.

The weaknesses also remain largely the same; the belief that somehow a kind of Christian rationality would overcome Britons and Germans alike and allow them to live in peace with each other as they were surely meant to live. It needed only someone to show them a way. There was also the sense that Britain must lead the way because she bore so much of the responsibility for past actions, an idea of course that goes along with the notion that Britain was still the great power in the world. There is a marvelous piece of correspondence from Catchpool, a very prominent Quaker, writing from Germany in 1939 suggesting seriously that the way to end all of this 


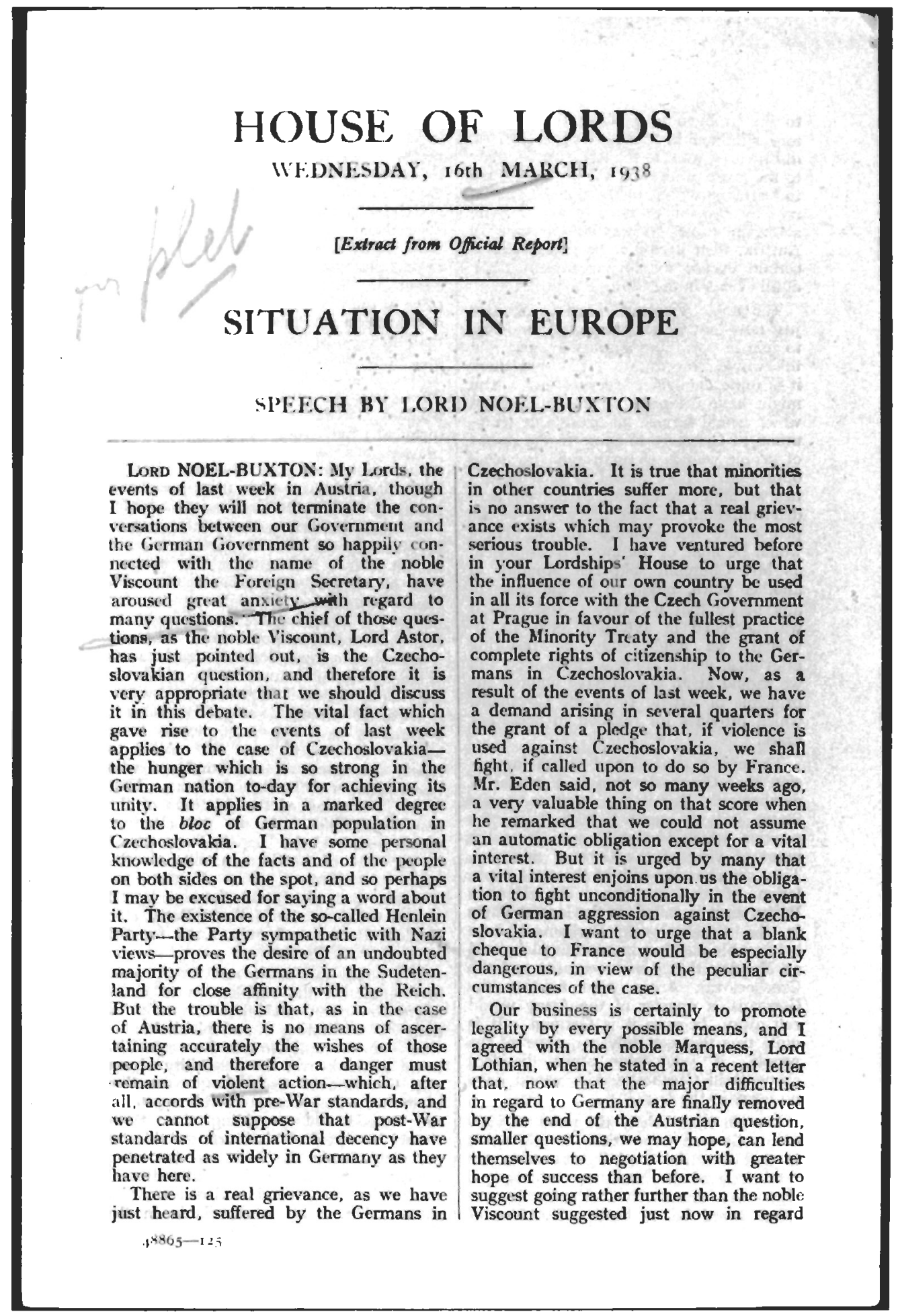

Figure 4. An offprint of Lord Noel-Buxton's speech in the House of Lords on the situation in Europe. (Noel Buxton Papers.) 
conflict was to offer the Germans the opportunity to join the British Empire!

On the other hand there is the same personal commitment, the same urge to travel and be on the spot, the same fearlessness in both the physical and the mental sense.

In 1933 he is off to Germany with his secretary (Cornwell-Evans), with Catchpool and Ben Riley (another M. P.) to see Rosenberg, Papen, Blomberg and Goebbels. They even obtained an interview with Hitler "...but it was a forlorn hope, as I had realized. He declared that everybody loved him, that if he went into the Linden (sic) a hundred thousand people would crowd to acclaim him. He soon took to raving against the Communists, and violently asserted that every Communist was a criminal. He shouted in this strain as if we were a public meeting, and we broke off the talk.";- Still he was back in Germany virtually every year until the outbreak of war; he gave advice to Nevile Henderson, the British Ambassador, to Lord Halifax and to Neville Chamberlain. He visited Czechoslovakia to see for himself how the Sudeten Germans lived. He corresponded with like-minded people like Arnold Toynbee and argued with those who moved further away from appeasement as Hitler's designs seemed to become clearer, like Lord Cecil. He lectured in Stuttgart in 1938 (Figure 5), he saw less possible 'reason' in the National Socialists than his brother but hoped that they would be overthrown and/or that because the German people were so obviously opposed to another war, even Hitler would hesitate to start one. is

During the first part of the war, Buxton merely increased his efforts to make peace. However, just as with his later interventions in Abyssinia, there was less patience, with his views. When Buxton wrote to Churchill expressing alarm over the proposal to alter Poland's boundaries by seizing German territory, the Prime Minister's answer showed little patience with the man he had once entrusted with diplomacy in the Balkans "...Your letter gives me the impression that you have not the slightest conception of the perils that lie ahead before we can establish a world peace order.' Fieldhouse suggests that "it was not in this tone Chamberlain and
Halifax or, at an earlier date, Lansdowne and Grey, had been wont to receive Buxton's advice, and one would suggest that the difference lay not only in the personalities of particular Ministers, but also in the great relative decline in British power and safety between Agadir and Yalta."

Churchill's rudeness was not likely to disturb Buxton's equanimity. That correspondence of 1944 was written when he was 75 years old. He was living in London, still involved in large numbers of projects and unintimidated by Prime-Ministers or flying bombs; of them he wrote: ${ }^{3 \prime}$

\section{"Robots meant to break our nerve,} Quite a different purpose serve,

Serve our purpose of the past

To live each day as if our last."

Making peace again escaped Buxton's grasp and the Peace Movement of which he had been such an important part still remains a relatively unexplored aspect of the war years. However, like the Balkan questions and Abyssinian slavery, it can be argued that, in the end, Buxton could not persuade enough people to follow his prescriptions for the ills of the world. Clearly he was incapable of bringing any degree of Christian charity to the greater political questions of the first half of the twentieth century. But surely he did make a difference.

\section{HUMANITARIAN CAUSES}

The third group of causes clearly illustrate this. They are among the least well documented aspects of his career in the McGill collection, nevertheless the concerns for the world's displaced persons, for refugees, for the children from areas of fighting or starvation, are increasingly in evidence during the last two decades of his life. He bombarded the relevant departments with memoranda asking for help and funds, he raised money, as always, himself. In 1930 he became the President of the Save the Children Fund in which he had had interests before. His compassion knew no international boundaries or colour bars." One may argue that all of Buxton's greater schemes ended in failure but no one can even begin to assess the number 
Noel Buxton: The 'Trouble-Maker' and His Papers
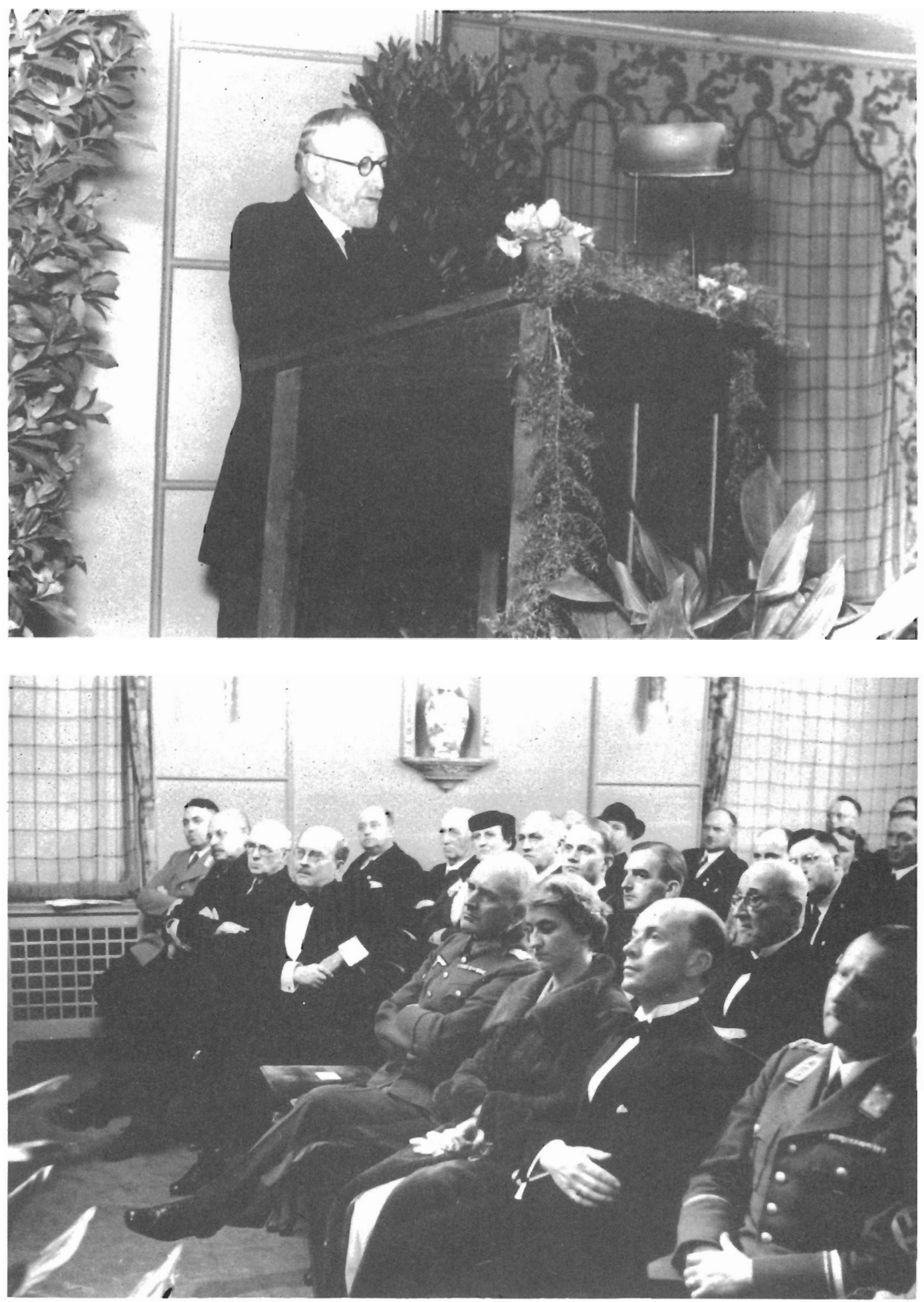

Figure 5. Lord Noel-Buxton addressing an audience at Stuttgart in 1938. (Noel Buxton Papers.) 
of individuals who were helped through his intervention. In that sense he was indeed a true Christian, there were no great political solutions but only a way of helping individuals cope with a very uncertain twentieth century life.

\section{THE BUXTON PAPERS}

The papers of a person with such an enormous range of interests stretching over a life of seventy-nine very active years cannot help but be very voluminous. Buxton wrote three books, collaborated in at least half a dozen others, wrote numerous and often lengthy articles for journals like the Contemporary Review, many pamphlets, innumerable letters to newspapers and made hundreds of speeches both in and out of Parliament and carried on a private correspondence of vast dimensions. It is likely that all of this material was once properly filed and indexed because Buxton's orderly working methods can dimly be discerned among the profusion of documents and notes scribbled on bits of notepaper. For instance when a letter of some importance came in, he would mark its most important sections in pencil and then apparently pass it to his secretary to type. Presumably the two copies were then filed in different places, which would account for the fact that in the collection there are sometimes original letters ${ }^{f 1}$ in one place and in another there are only typed copies. Moreover it is difficult to know what has failed to survive. The unfortunate history of the disposition of the papers creates some uncertainty with regard to the number of documents missing. Nevertheless the collection at McGill is very substantial; it is housed in 68 box-files, a filing cabinet containing some ninety files, two large tin boxes containing some miscellaneous material and a number of bound folders with type-written notes on books and carboncopies of correspondence on a variety of unrelated subjects. There are also copies of various journals mostly with articles by Buxton in them.

There is a finding aid which is helpful for everything except that which is still housed in the tin-boxes, papers in these boxes certainly need some further sorting. The file folders, not numbered, contain type-written notes on books which interested Buxton, and form a good indication of the kind of material which he considered important.

The collection at Duke University appears to be considerably smaller containing only some 1,100 items. A finding aid for this collection may be found in the Department of Rare Books and Special Collections at McLennan Library. A nother collection which would no doubt be useful in relation to Noel Buxton's political career is the collection of the papers of Charles Roden Buxton which are housed in Rhodes House Library, Oxford. Noel Buxton was not only fond of his brother and travelled a great deal with him but also looked up to him as a man of considerable intellect. A calender of the Charles Buxton papers is also to be found in the Department of Rare Books and Special Collections.

The Buxton papers are an important tool for anyone doing research in British Foreign policy over the whole span from 'Agadir to Yalta'. They no doubt reflect the views of a 'trouble-maker', of a dissenter of a rather special kind. But few men could be as representative of the kind of high minded Christian, who found the Liberal Party no longer acceptable for foreign policy reasons and moved to Labour and deeply influenced it in its early years. Indeed as long as people such as Buxton were part of that Party, it represented a broad spectrum of British opinion. Their views, therefore, are indispensible for any understanding of British history in the first half of the twentieth century. Fieldhouse understood this ${ }^{42}$, and understood, as did Taylor ${ }^{32}$ that some time would need to pass before these 'dissenters' would find their proper place in that history. The collection at McGill enables us to help in this endeavour, enables us also to come close to a man who, for all his failures, had much to offer us in the way he looked on the world. Whenever he was perplexed, Buxton tells us, he would wander to Westminster Abbey and look at the plaque erected for his great grand-father, Sir Thomas, which read:

'Endowed with a vigorous and capacious mind 
Of undaunted courage and untiring energy,

He was early led by the love of God, To devote his talent to the good of man.'

\section{Notes}

1. Prof. Fieldhouse was Kingsford Professor of History, (1945-1966), Chairman of the History Department, (1947-1961), Dean of McGill College, (1948-1961), Vice-Principal (Academic), (1961-1966).

2. Mosa Anderson, Noel Buxton, A Life. London: George Allen and Unwin Ltd., 1952.

3. A Guide to the Papers of British Cabinet Ministers, 1900-1951. compiled by C. Hazlehurst and C. Woodland (London, 1974), 25-26.

4. I am grateful to Dr. Richard Virr for drawing my attention to Sotheby's catalogue and the Guide to the Papers of British Cabinet Ministers. The Sotheby's catalogue is for 22nd and 23rd July 1985.

5. Prof. Fieldhouse laid the foundation of his study of Buxton in A Century of Conflict 1850-1950: Essays for A. J. P. Taylor. Edited by $M$. Gilbert. London, 1966. His essay was entitled 'Noel Buxton and A. J. P. Taylor's Trouble Makers'. Only Taylor would have the audacity to review a book published in his own honour, but in his review, which appeared in The Observer Review, 20th Nov. 1966, Taylor, claiming that he is really the only person qualified to review the book, shows much appreciation of the Fieldhouse essay and reminds his readers of the friendship between himself and Fieldhouse "which has now extended over nearly forty years.'

6. See for instance Paul Bloomfield, "More Pleasures of Genealogy," The Listener, 17 July, 1947 , an article which is concerned with the Buxton family and which begins as follows: 'It must have been about 1910: an empty train was shunted from a London station into the yards. It wasn't quite empty, for a railway servant who happened to be there (so the story goes, and I believe it's true) saw a man jump down from one of the carriages. The peculiar thing about him, apart from his presence there at all, was that he had no trousers on-instead, he had a newspaper wrapped around his legs. This unexpected person said to the railway man, without embarrassment: 'I'm the President of the Board of Trade. Do 
you think you could get me some trousers?' I can't remember whether the answer was ' $\mathrm{Ho}$, yus?'or something more skeptical than that. The point is, it was the President of the Board of Trade: he had lost his trousers while shaking ants out of them in the Micheldever tunnel. You see the details are circumstantial. Sydney Buxton was his name; he was afterwards Governor of South Africa... and he was not the first of his blood to appear unconventionally dressed in a more or less public place. He was the the sixth in line of descent from Robert Barclay who in 1672 had walked through the streets of Aberdeen in sackcloth.

7. The purchase and restoration of Paycockes House in Coggeshall was one of the great joys in Noel Buxton's life. It was fully restored to its mediaeval splendour and he lived in it for a short while, then gave it to the National Trust in 1920. Box 19 contains much material relating to this project as well as many photographs. Andrew Noel was knighted by Queen Elizabeth I. Unlike the Buxtons, the Noels fought on the Royalist side in Civil War.

8. Charles Middleton (Lord Barham) apparently was instrumental in interesting Wilberforce in the cause of the Slave Trade. Wilberforce visited Barham Court where he met the Rector of Teston, who had been a Chaplain in the West Indies and who could testify to the horrors of the Trade. See G. W. E. Russell, Lady Victoria Buxton: a Memoir (London, 1919), 2-3.

9. There are four file folders dealing with the proposed biography of Sir T. F. Buxton among the Buxton papers.

10. Joseph Pease was the first Quaker to sit in the House of Commons in 1828 .

11. His father became the Governor of South Australia in 1895 , but no one could foresee this in 1892. His father was not likely to take such an appointment because of the fragile health of his mother. The memoir by G. F. E. Russell on Lady Victoria Buxton deals in considerable detail with the Australian interlude of Buxton's parents.

12. Travels and Reflections by the Rt. Hon. Noel Buxton, M. P. London: George Allen and Unwin Ltd., 1929.

\section{Boxes 9 to 14.}

14. He thought there should only be life peers.

15. Two short notes in the Papers give a good indication of Buxton's attitude towards office and title. On July 17th, 1924, he has a real debate with himself about whether he should pursue reform rather than take office, it concludes: 'I doubted my capacity to do credit to the Party or to my religion or myself, but concluded that if I exercised faith, $\&$ as I had not sought office, and was thought capable, I should not fail. I saw that my motive for reluctance was fear $\&$ I arrived at a religious conviction that it was right to go ahead.' In 1935 he got a anonymous post-card which berated him for taking the title and which among other things called him a humbug and a hypocrite ('But thank goodness the so called 'Working' classes are beginning to see through the people who, under the cloak of Religion and 'Philanthropy' and 'interest' in the working classes, are simply feathering their own nests and retaining for themselves position and privilege.'). He circulated a copy of this to members of his family and asked for comments. He wondered whether the moral influence of the family had been diminished as a result of his action. A number of hand written replies are attached.

16. There are three boxes $(22,23,24) \mathrm{con}$ taining the correspondence of Lady Lucy Buxton with her constituents on a variety of issues.

17. There are nevertheless several bundles of letters dealing with various matters relating to elections and letters from constituents. Chapter IX of the draft autobiography also deals with Buxton's early years in the House of Commons. It is in Box 11 .

18. A. J. P. Taylor, The Trouble Makers, Dissent over Foreign Policy 1792-1939, London, 1957. In this brilliant series of lectures, Noel Buxton finds himself in the company of the great dissenters in British Foreign Policy, beginning with Fox.

19. Known naturally as 'National Liberation Movements' of one kind or another, they were also reflections of the interests of the various 
Balkan states and Greece, all designed to gain bits of Macedonian land. The Internal Macedonian Revolutionary Organization was the spearhead of the revolt of 1903 . It was also this organization which engineered the spectacular kidnapping of an American Missionary, Ellen Stone, in September 1901. The U.S. Government started the twentieth century by paying $\$ 66,000.00$ for her release.

20. Boxes 25, 57-65, 1 large unnumbered Box and some 20 files, sorted roughly by time.

21. During the Bosnian Crisis of 1908 Aehrenthal, the Austrian Foreign Minister is particularly unhappy about the 'English travellers', Mr. Buxton in particular. See the Austrian Diplomatic Documents (OsterreichUngarns Aussenpolitik von der Bosnischen Krise 1908 bis zum Kriegsausbruch, 1914, ed. Pribram, etc. Wien, 1930). e.g Doc. No. 768, Dec. 17th 1908, see also Doc. 692, Thurn's report from Sofia. The British Ambassador in Vienna, Sir Fairfax Cartwright, passes Aehrenthal's 'bitter complaints' on to Sir Edward Grey, Dec. 24th 1908. British Documents on the Origin of the War, 1898-1914, vol V., ed. by Gooch and Temperley, London, 1927. Both historians were at one time or another members of the Balkan Committee, but Gooch, in particular, was a close friend of Buxton's.

22. For some of the complications of British policy towards Austria-Hungary and the Balkan problems see R. Vogel The Diplomatic Career of Sir Fairfax Cartwright, 1906-1913, M.A. Thesis, 1954 McGill; and R. Vogel 'Sir Fairfax Cartwright and the Balkans,' The New' Review, 1965. And other such items of selfadvertisement useful for the citation index.

23. It is a point made by Taylor, op. cit. p. 17-18.

24. The Contemporary Review was a journal to which Buxton contributed on a fairly regular basis until his death. It is significant that in the U.S. this article was reprinted in a World Peace Foundation Pamphlet, jointly with Mrs. Stobart's article, also from the Contemporary Review on 'Women and the War'. Buxton was in charge of the British relief work in the Balkans and had encouraged and paid for the British Women's Convoy
Corps which was organized by Mrs. Stobart. These women's corps were generally active in the Balkans both in these wars and in the Great War. This hospital was in fact entirely staffed by women, as was its famous successor the Scottish Women's Hospital for Foreign Service, run by Dr. Inglis, Chief Surgeon of the Edinburgh Hospital and Dispensary for Women and Children. These organizations were closely associated with the various suffrage movements. They had Buxton's strong support throughout his career.

25. 'What is the distinction between horrors to tell [and] horrors to conceal? It lies surely in the difference between evils removable and irremovable. If war and neglect of wounds are a fixed quantity, the less said the better. Let us leave Zola's "La Debacle" to the prurient and the idle. But, clearly, the diminution of pain in war has been one of the aims most unanimously pursued...... The problem is vital, and for its solution it is essential to the know the facts' Buxton, "The Wounded, Contemporary Revieu, (February 1913), 1.

26. In 1919 Buxton was in Budapest after the occupation of the city by Rumanian troops. He was appalled at the conditions prevailing in that city. [Box 30$]$. He was in the city to report on the refugee problem.

27. The Anti-Slavery Reporter and Aborigines Friend, Series V, Vol 26, No. 2 (July 1936).

28. Boxes 66-68 and 24 files.

29. H. N. Fieldhouse Noel Edward Buxton, the Anti-Slavery Society and British Policy with respect to Ethiopia, 1932-44. Canadian Historical Association, Historical Papers, 1972.

30. Buxton recognized that Ethiopia was an Empire in which the subject people were often treated as slaves, quite literally. See Fieldhouse, 288 and footnote 6.

31. Fieldhouse, 307-308.

32. Boxes 32-41, 46-49, 51-55 plus 27 files. This includes correspondence on Peace Movements etc. It does not include the correspondence which is in the 'Special Correspondence boxes (Boxes 1-8)-these are arranged in alphabetical order. Much of the 
correspondence with Prime-Ministers, Foreign Secretaries etc., is naturally concerned with matters of war and peace.

33. The other work is the biography of Buxton by M. Anderson (see fotenote 2). Much of Anderson's book is devoted to Buxton's attempts to reconcile Britain and German, and with the Peace Movements in which he participated. It was, of course, published twenty years after Corwell-Evans' book.

34. Buxton went travelling with Ramsay MacDonald in the Sahara, see Travels and Reflections, 210.

35. "The Anglo-German War of 1939-1942; some movements to end it by a negotiated Peace." Transactions of the Royal Society of Canada, 1971.

36. Box 2-Special Correspondents. Catchpool.

37. Anderson, 127.

38. Ibid. p. 142-letter to the Times, 5 April, 1939.

39. Box 13: Draft of Autobiography.

40. Boxes 30 and 31 contain material on Refugees and the Save the Children Fund.

41. Part of the time covered by these papers is one in which the Prime-Minister of Great Britain still apologized for replying to a personal letter with a typed rather than a handwritten answer.

42. Prof. Fieldhouse proposed to publish an annotated version of the draft auto-biography which exists in the papers. Unfortunately he died before he could begin this project.

43. See specifically Chapter 1 of The TroubleMakers, e.g. "The Dissenters existed: therefore they deserve to be put on the record. They cannot be passed over by anyone who is studying British foreign policy in its official form; and they appear in all the books if only as 'noises off." (p. 15.) 